\title{
EL ANTICLERICALISMO Y SUS CONSECUENCIAS EN LAS DIÓCESIS GALLEGAS DURANTE EL PERÍODO DE LA II REPÚBLICA (1931-1936) ${ }^{1}$
}

\section{THE ANTICLERICALISM AND ITS CONSECUENCES IN THE GALICIAN DIOCESE DURING THE PERIOD OF THE II REPUBLIC (1931-1936)}

\author{
JOSÉ RAMÓN HERNÁNDEZ FIGUEIREDO \\ Instituto Teológico Compostelano \\ Instituto Teológico “Divino Maestro" Ourense
}

\begin{abstract}
Resumen
En este artículo se recoge el dolor y la desolación de tantas ciudades, villas y aldeas gallegas, que padecieron la violencia de la zarpa revolucionaria, especialmente durante la primavera "trágica" del 36. Su elaboración es posible gracias a la apertura oficial a los investigadores de los documentos del Archivo Secreto Vaticano correspondientes al pontificado de Pío XI, por el Papa Benedicto XVI. Estos informes enviados por obispos, vicarios generales o vicarios capitulares, según las circunstancias, presentan desmanes, asaltos y destrozos, incendios, agresiones y encarcelamientos. Los indicadores históricos o de sociología religiosa que enmarcan estos desmanes antirreligiosos, ayudan a comprender e interpretar los datos expuestos y a entender que realmente existió una persecución religiosa bajo el régimen de la II República en Galicia.
\end{abstract}

\section{Palabras clave}

II República - Archivo Secreto Vaticano Galicia - anticlericalismo - incendios.

\section{Abstract}

This article shows the pain and desolation of so many galician cities, towns and villages which suffered the violence of the revolutionary hand,specially during the tragic spring of ' 36 . Its preparation is posible thanks to the oficial opening to the researchers of the documents of the Vatican Secret Archive corresponding to the papacy of Pío XI, by the Pope Benedict XVI. These files sent by Bishops and general Vicars, depending on the circumstances, present outrages, raids and damages, fires, aggressions and inprisonments. The historical or religious sociological indicators which provide the setting for these antireligious outrages, help to comprehend and interpret the presented information and to understand that there really existed a religious persecution under the regime of the II Republic in Galicia.

\section{Keywords}

II Republic, Vatican Secret Archive, Galicia, Anticlericalism, fires.

\footnotetext{
${ }^{1}$ Entregado el 21.05.2008.
} 


\section{INTRODUCCIÓN}

La enorme riqueza artística de España, que cuenta con monumentos desde la prehistoria hasta el momento actual, ha sufrido daños en muchas ocasiones. Las guerras, revoluciones, los fenómenos naturales... han ido mermando este singular conjunto de arte. En los tiempos contemporáneos es cuando más fuertes y lamentables han sido los desperfectos y pérdidas.

En primer lugar, la francesada de 1808 a 1814, cuando a las múltiples destrucciones por causa de la lucha armada, se unió el expolio sistemático de obras de arte, previamente planificado, que pasaron a manos de los invasores. Luego vino la funesta ley de la desamortización de los Bienes Eclesiásticos de Juan Álvarez Mendizábal, que sacó a la pública almoneda todos los conventos y casas de religiosos de España. No supuso una destrucción inmediata, aunque en sus inicios se produjeron grandes incendios en el verano de 1835 en Zaragoza, Barcelona, Reus, y otras ciudades, sino el sucesivo uso inadecuado de los monasterios que, faltos de cuidados, se fueron arruinando, y en otros casos, convertidos en corralizas o establos, sufrieron daños continuos y persistentes ${ }^{2}$.

Cuando las guerras carlistas hubo de nuevo sensibles pérdidas y modificaciones de iglesias que en ocasiones se fortificaron, desfigurándolas. A comienzos del siglo XX se dio el caso lamentable de la Semana Trágica, en julio de 1909, cuando los conventos de Barcelona fueron en gran parte incendiados. Pero nada fue comparable con lo que sucedió en el curso de la Segunda República en toda España y de la guerra civil en la zona republicana. Nunca en la dilatada historia de España se había producido un conjunto de daños y agravios tan importante.

Aunque también hubo daños en casas particulares y edificios públicos, así como en monumentos de carácter profano, fue en los edificios religiosos donde se centró principalmente el odio destructor. Para explicar lo inexplicable se habla siempre de milicias ciudadanas e incontrolados que serían los únicos responsables de los incendios sacrílegos, mientras las autoridades españolas solamente intentaron evitar el estrapalucio. Si así fuera, un gobierno que tenía que ir a la zaga de unos incontrolados era sencillamente un gobierno que apenas controlaba nada, por lo que su calificación de gobierno resulta gratuita ${ }^{3}$.

2 REVUELTA GONZÁLEZ, Manuel, El estallido anticlerical de 1834, en XX Siglos III, 11 (1992), pp. 136-141; MOLINER PRADA, Antonio, El anticlericalismo popular durante el bienio 1834-1835, en HispSac IL (1997), pp. 497-551.

${ }^{3}$ BASSEGODA I NONELL, Joan, La arquitectura profanada. La destrucción sistemática del patrimonio arquitectónico religioso catalán (1936-1939), Barcelona: Editorial Mare Nostrum, 1990, pp. 7-14. 
En este artículo se recoge todo el dolor y la desolación de tantas ciudades, villas y aldeas gallegas, que padecieron la violencia de la zarpa revolucionaria, especialmente durante la primavera "trágica" del 36. Su elaboración es posible gracias a la apertura oficial a los investigadores de los documentos del Archivo Secreto Vaticano correspondientes al pontificado de Pío XI, el día 30 de junio de 2006, por el Papa actual, Benedicto XVI. Dicha apertura puso a disposición de las investigaciones históricas, en los límites de los reglamentos, todas las fuentes documentales hasta febrero de 1939 conservadas en las distintas series de los Archivos de la Santa Sede y principalmente en el Archivo Secreto Vaticano y en el Archivo de la Segunda Sección de la Secretaría de Estado, entonces llamada Congregación de los Asuntos Eclesiásticos Extraordinarios ${ }^{4}$.

La colección de informes vaticanos inéditos que publicamos, limitada al período que va del 14 de abril de 1931 al 18 de julio de 1936, quiere ser sólo una aportación de base para la historia político-religiosa de aquellos cinco años. No se intenta elaborar de un modo completo y acabado esa historia, ni tampoco emitir un juicio concienzudo y definitivo sobre las personas y los hechos que aparecen en estos documentos, sino que se limita, modestamente, a aportar documentos para la historia de este período.

Estos informes enviados por obispos, vicarios generales o vicarios capitulares, según las circunstancias, no se limitan al mero y frío dato estadístico, que siendo cierto, daría una idea mucho menos real que la exposición de lo sucedido día a día en las ciudades y pueblos de España, llegando incluso en algunos casos, a la descripción detallada de estos desmanes, de los asaltos y destrozos, de los incendios y tiroteos, de las agresiones y encarcelamientos. El historiador José Pla advierte que en algún momento se llega a confundir la historia de España de este período con la relación de los hechos de violencia ${ }^{5}$.

Por otra parte, los indicadores históricos o de sociología religiosa que enmarcan estos desmanes antirreligiosos ayudan a comprender e interpretar los datos expuestos y a entender que realmente existió una persecución religiosa ${ }^{6}$. Sería interesante

\footnotetext{
${ }^{4}$ BSPSS, n. 0340, 30 de junio de 2006.

${ }^{5}$ PLA, José, Historia de la Segunda República, Barcelona 1940, t. IV, pp. 290-300.

${ }^{6}$ La bibliografía sobre el tema es inmensa. Aquí sólo hago referencia a algunos de los estudios más importantes. El ya citado MONTERO MORENO, Antonio, Historia de la persecución religiosa en España. 1936-1939, Madrid: BAC, 1999³; CÁRCEL ORTÍ, Vicente, La Iglesia durante la II República y la Guerra Civil (1931-39), en Historia de la Iglesia en España, ed. Ricardo GARCÍA VILLOSLADA, Madrid: BAC, 1979; ID., La persecución religiosa en España durante la Segunda República (1931-1939), Madrid: Ediciones Rialp, 1990²; ID., Mártires españoles del siglo XX, Madrid: BAC, 1995; ID., Buio sull'altare. La persecuzione religiosa spagnola, 1931-1939, Roma: Città Nuova, 1999; MARTÍN RUBIO, Ángel David, La persecución religiosa de 1936-1939: estado de la cuestión y propuestas historiográficas, en HispSac 49 (1997), 43-71.
} 
recordar aquellas palabras de la Instrucción Pastoral que publicó la Comisión Permanente de la Conferencia Episcopal Española, con motivo del cincuenta aniversario del comienzo de la guerra civil española. Entre otros extremos, decía:

la misión pacificadora de la Iglesia nos mueve a decir una palabra de paz con ocasión de este aniversario. Tanto más cuanto que las motivaciones religiosas estuvieron presentes en la división y enfrentamiento de los españoles. No sería bueno que la guerra civil se convirtiera en un asunto de que no se pueda hablar con libertad y objetividad. Los españoles necesitamos saber con serenidad lo que verdaderamente ocurrió en aquellos años de amargo recuerdo. Los estudiosos de la historia y de la sociedad tienen que ayudarnos a conocer la verdad entera acerca de los precedentes, las causas, los contenidos y las consecuencias de aquel enfrentamiento. Este conocimiento de la realidad es condición indispensable para que podamos superarla de verdad. Por ello hay que desautorizar los intentos de desfigurar aquellos hechos, omitiendo o aumentando cualquiera de sus elementos a favor de una posición determinada o en contra de personas, ideologías o instituciones. En ningún caso se debe utilizar una imagen distorsionada de lo ocurrido como argumento a favor o en contra de nadie en la actual situación española. Tal procedimiento podría avivar los rescoldos de la división todavía no apagados del todo y perpetuar en las generaciones jóvenes actitudes de intolerancia de consecuencias insospechables... Aunque la Iglesia no pretende estar libre de todo error, quienes le reprochan el haberse alineado con una de las partes contendientes deben tener en cuenta la dureza de la persecución religiosa desatada en España desde 1931. Nada de esto, ni por una parte ni por otra, se debe repetir. Que el perdón y la magnanimidad sean el clima general de los nuevos tiempos?

Concluyendo, han pasado suficientes años como para poder estudiar los hechos serenamente y con la suficiente objetividad que garantice la claridad de juicio. Las fuentes, sinceramente realistas, enormemente humanas, reflejan la vivencia fiel de aquellos acontecimientos en circunstancias enormemente adversas y hostiles.

Esto no priva de la necesidad de perdonar y reconciliarse, lo que no está reñido con la verdad histórica. Sería injusto si desde la misma Iglesia calláramos, ocultando, ignorando - o, peor aún, negando - los resultados de una investigación objetivamente histórica sobre los mismos. Se hace preciso estudiar la historia, prefiriendo los datos objetivos antes que las opiniones subjetivas que se puedan haber creado interesadamente en un momento cronológicamente posterior ${ }^{8}$.

${ }^{7}$ Constructores de paz, en BOCEE III, 9 (enero-marzo 1986), p. 15.

8 GUIJARRO GARCÍA, José Francisco, Persecución religiosa y guerra civil. La Iglesia en Madrid, 1936-1939, Madrid: La Esfera de los Libros, 2006, p. 19. 


\section{DESDE MAYO DEL 31 A FEBRERO DEL 36}

Apenas transcurridos los primeros días de estentórea euforia y júbilo popular por la proclamación del régimen republicano, los elementos extremistas expresaron claramente su disconformidad con los procedimientos, que estimaban claudicantes y benignos, del nuevo Gobierno. Sirvió de pretexto la inauguración de un centro monárquico en Madrid, para que las llamas de los incendios de más de un centenar de iglesias y conventos en las principales ciudades españolas, durante tres días de barbarie popular, demostraran la presencia viva y decidida de un sector violentísimo dispuesto a imponerse por el terror, incluso al Gobierno provisional de la República ${ }^{9}$.

El 11 y 12 de mayo, ante la inhibición complaciente de la autoridad, tan parecida a la complicidad, ardieron en el centro y en las barriadas extremas de muchas ciudades españolas, infinidad de iglesias, conventos y edificios, siendo otros muchos saqueados y destrozándose en todos ellos famosas obras de arte ${ }^{10}$.

Apenas habían pasados dos meses, y la situación de los conventos religiosos en España continuaba siendo insegura. Prácticamente las consecuencias y depuraciones que se habrían de seguir por los sucesos graves de mayo de 1931, no tuvieron relevancia. Fueron muchos los que creyeron que en esas jornadas de ignominia no se habían quemado únicamente los templos, las bibliotecas, las imágenes y las pinturas, testimonios de arte, de la piedad y de la cultura, sino que en las piras había ardido, también, el propio régimen ${ }^{11}$.

El nuncio Tedeschini en un despacho dirigido al secretario de Estado, el cardenal Pacelli, expone a grandes rasgos la sensación de inseguridad y preocupación todavía reinante, ya que afirma que son "frequenti i tentativi di assalti che quà e là si vanno ogni tratto ripetendo"12. En este sentido, informa del suceso ocurrido en La Coruña, que define como uno de los intentos que tristemente ha tenido éxito.

\footnotetext{
${ }^{9}$ PLA, José, Historia de la Segunda República, o.c., t. I, p. 122.

${ }^{10}$ La descripción de estos sucesos, con fotografías de los edificios destruidos por llamas, cfr. ARRARÁS IRIBARREN, Joaquín, Historia de la Cruzada Española, Madrid: Editora Nacional, $1964^{2}$, t. I, pp. 304-360.

${ }^{11}$ ARRARÁS IRIBARREN, Joaquín, Historia de la Segunda República, Madrid: Ediciones Españolas, 1940, Madrid: Ediciones Españolas, 1940, t. I, p. 100.

${ }^{12}$ Despacho del nuncio al secretario de Estado. Madrid, 6 de julio de 1931, en ASV, Arch. Nunz. Madrid, busta 925, tit. VI, rub. XV, f. 138 r.
} 


\subsection{Incendio en La Coruña}

Se trata del incendio del convento de los Capuchinos de esta capital gallega que acaece el día 2 de julio de 1931. Ya precedentemente los religiosos habían abandonado sus residencias, pero las turbas anticlericales no contentas con eso, después de reunirse en un comité promovido por la federación obrera local, decidieron impedir que los religiosos regresaran a los conventos, y empezaron a proferir gritos dando a entender que el pueblo debía hacer cumplir inmediatamente su voluntad. Y, así mientras una parte de los promotores presentaron su decisión al Gobernador Civil, un grupo más reducido, formado de chiquillos y mozalbetes, se encaminó hacia los conventos comenzando a arrojar contra los mismos una lluvia de piedras, tirando la primera un niño de once años.

Asaltaron las casas de los Padres Jesuitas y de los Hermanos Maristas, a pesar del intento de disolución de la turba revolucionaria por las fuerzas de Seguridad. Después se dirigieron al convento de los Capuchinos. El edificio estaba vigilado por cuatro guardias que intentaron hacer desistir a los asaltantes, al decirles que el edificio había sido abandonado por los religiosos. Pero, todo fue inútil: los asaltantes entraron en el edificio, mientras otros incitaban desde fuera al incendio, lo que no tardó en acontecer. Se llamó a los bomberos que no pudieron hacer gran cosa, porque por dos veces la labor de extinción se vio impedida por los revolucionarios al picar con navajas las mangueras. Finalmente, llegó un grupo de guardias que para dispersar a la turba ígnea hubieron de hacer uso de las armas, quedando heridos media docena de los rebeldes, todos menores de veinte años a excepción de uno. Mientras se acometía la acción policial, se venía abajo el tejado del convento, con el consiguiente riesgo en las casas vecinas.

Esto no fue todo, y de seguido se dirigieron al convento de Dominicos con la misma intención de incendiarlo, pero en esta ocasión se lo impidió la fuerza militar. Aprovechando el presente despacho, el nuncio también informa del incendio de la iglesia parroquial de Villa del Río, en la provincia de Córdoba, que tuvo lugar el día anterior y quedó totalmente destruida. Se lamenta de que estos desmanes siguen y no sin éxito en más de un caso, condenando asimismo que las autoridades no hayan mostrado una seria voluntad de "reprimere questi movimenti insani e sopratutto se non si imporranno castighi esemplari ai colpevoli"13.

Transcribimos a continuación la noticia de este suceso tal como aparece presentada por la prensa El Ideal Gallego, cuya línea editorial es de corte católico, regionalista e independiente. Así, lo intitula: "El Convento de los Capuchinos,

${ }^{13}$ Ibíd., ff. 138r-139r. 
incendiado. Salen las tropas a la calle. A la una y media de la noche renace la tranquilidad". He aquí su contenido:

"Nuestra protesta: Con más pena que indignación y no es pequeña la que sentimos, levantamos nuestra voz para protestar contra los hechos incalificables que ayer presenció La Coruña. Bastó que un periódico dijese que se reanudaba el culto en la iglesia de los Capuchinos para los que elementos del anticlericalismo coruñés promoviesen la celebración de un mitin en la plaza de Toros para protestar. Así dijeron contra el Gobierno por autorizar sin consentimiento del pueblo, la vuelta de los religiosos a sus casas de las que habrán sido expulsados por ese mismo pueblo que nadie ha visto. Nada de particular ocurrió en la reunión; pero poco después un grupo en el que predominaban chiquillos y mozalbetes apedreó las residencias de los Jesuitas y de los Maristas rompiendo numerosos cristales. De allí fueron a los Capuchinos; tras una intensa pedrea surgió el incendio. Ruegos y súplicas de los vecinos, nada lograron.

He ahí los hechos. La indignación sube del pecho a los labios para condenar la maldad de los inductores que azuzan a irresponsables por ignorantes y por engañados a la realización de tan vandálicos hechos; la pena se sobrepone a todo otro sentimiento al considerar que existe una ciudad que permite la consumación de tales hechos: mientras la banda militar da un concierto en el Relleno y las orquestas animan bares y cafés, los bajos fondos de la capital consuman un gravísimo atentado contra el derecho de gentes.

Los católicos hemos aceptado el cambio de régimen, cooperamos al mantenimiento del orden y de la paz pública en forma irreprochable. ¿Quién puede achacar a los católicos coruñeses la comisión del menor acto de hostilidad a la República? A esta conducta se contesta por unos que se titulan republicanos, no podemos creer que lo sean, negándonos todo derecho a profesar libremente nuestra religión; por otros, incluyendo en ellos a las autoridades, abandonándonos a las furias de los que recurren a vías de hecho. Y, ¡ay nosotros si nos defendemos! ¡se nos trata como provocadores dignos de todos los castigos! Parece que se tiene el propósito de lanzarnos fuera de la legalidad.

No nos basta decir una y otra vez que las órdenes religiosas viven al amparo de la ley, que si en algo se salieron de ella son las autoridades, los tribunales, las Cortes las llamadas a decir la última palabra, pero no grupos de indeseables que echando por delante ideales no sentidos de lo que tratan es de lucrarse a través de las catástrofes por ellos provocadas.

Acaso sea este uno de los últimos llamamientos que hacemos a la concordia civil. Los católicos queremos y anhelamos la paz; no nos negamos a acatar lo que las autoridades superiores pactan con los Gobiernos. Lo que no podremos tolerar es que se nos trate como parias y que se nos entregue como víctimas propiciatorias al odio anticatólico.

Nota informativa: el mitin fue convocado por la Federación local para las siete de la tarde en la Plaza de Toros. Se quería protestar contra el Gobierno que autorizaba la reintegración a sus casas de las Órdenes Religiosas. Asistieron unas 2000 personas. 
El presidente dijo que se elevaba un mensaje al Gobierno diciendo que era voluntad del pueblo que las Congregaciones religiosas no vuelvan a ocupar los edificios que antes habitaban en tanto no resuelvan las Cortes Constituyentes. Algunos del público gritan que el pueblo cumpla su voluntad ahora mismo. Después de la intervención de un espontáneo se dio por terminado el acto. Algunos de los concurrentes van al Gobierno Civil a entregar las conclusiones.

Los primeros incidentes: parecía ya todo terminado, cuando hacia el ensanche se formó un pequeño grupo formado casi exclusivamente por niños y mozalbetes. Unos y otros llevaban piedras en los bolsillos. Pronto se inició una pedrea contra la residencia de los Jesuitas, la cual se propagó a la de los Maristas, que está en frente de la anterior en la calle de Payo Gómez. Se nos informa que un chicuelo de unos once años fue el iniciador del acto. Una pareja o dos de Seguridad despejaron fácilmente.

Hacia los capuchinos: el grupo se encaminó al convento de los capuchinos sito en el barrio de Santa Lucía. Les seguía, según nos dicen, una pareja de Seguridad. El grupo estaba integrado principalmente por limpiabotas. Como cabecilla figuraban un sujeto muy conocido de la policía. Llevaban un cartel alusivo a la manifestación que realizaban.

En los capuchinos: poco después de las nueve y media, llegó el grupo ante la puerta de la residencia de los PP. Capuchinos, emplazada en la bifurcación de la travesía de Santa Lucía y Juan Flórez. Allí se encontraban de servicio los guardias de Seguridad, Gregorio Cancio, Constantino Torres, Ángel Verdeal y Bernardino Penas. El grupo de manifestantes, sin hacer caso a las indicaciones de los citados agentes - que les advertían que no había nadie dentro del edificio - penetraron en él en gran número, mientras los que estaban fuera les gritaban que prendiesen fuego. Instantes después de salir los revoltosos, el guardia Penas observó que dentro de la residencia había fuego, y entonces dieron aviso al parque de bomberos, de donde salió un retén. Al propio tiempo que el servicio de bomberos llegaba y emplazaba las mangas para la extinción, fueron éstas picadas con navajas por un grupo de los incendiarios, que recibió hostilmente a aquéllos. Un retén de Seguridad que se presentó en el lugar del incendio fue recibido con silbidos y a pedradas, por las turbas, viéndose obligadas las fuerzas a repeler la agresión, haciendo uso de las pistolas. El orden se impuso inmediatamente y por varias personas fueron recogidos los heridos, que eran seis.

Se llaman Hermenegildo Alonso Garza, de 17 años, que vive en Amargura 7, soltero, barbero, que sufre una herida de bala con orificio de entrada a nivel de la octava vértebra lumbar, pronóstico grave. Juan García Veira, de 18 años, soltero, tipógrafo, que vive en Cordelería 17, bajo, de herida de bala en la pierna derecha, con orificios de entrada y salida. Ramón Fábregas Fernández, de 18 años, domiciliado en Juan Flórez, 176, de una herida producida por rebote de bala en el labio superior, que le atraviesa en todo su espesor y pérdida de un diente. Manuel Pinilla Pan, de 17 años, barbero, que vive en José Lombardero, de heridas incisas en el párpado superior derecho, nariz y pierna derecha. Benedictino Loureda Vázquez, de 19 años, con domicilio en la Vereda del Polvorín, de una herida por desgarro en la región glútea derecha. Manuel González Vinagre, de 42 años, que vive en la calle de Juan Castro Mosquera, n. 23, de una herida contusa de tres centímetros en la pierna derecha. También fue asistido el ujier del ayuntamiento señor Concheiro, de una herida en el cuello que 
parece sufrió al caerle un cristal de uno de los edificios incendiados. Se hospitalizó al primero, pasando los demás a sus domicilios. Entre las protestas de un sector del público, comenzaron los trabajos de extinción, pidiéndose a los parques nuevas mangas que también fueron picadas.

Con la natural deficiencia en el servicio, siguieron los bomberos actuando, pero el fuego se propagó rápidamente a las casas contiguas, que tuvieron que ser desalojadas por los vecinos. El voraz elemento, a la una de la madrugada, había destruido totalmente la capilla de los capuchinos, la casa en que tenían su residencia y amenazaba destruir la totalidad de la manzana, constituida por cinco casas. En el lugar del siniestro hay fuerzas de las Guardia Civil y de Seguridad. En las primeras horas de la madrugada, iba a ser operado Hermenegildo Alonso Garza.

En la ciudad vieja: Al mismo tiempo que el incendio se enseñoreaba de la residencia de los Capuchinos, se dijo que comenzaba a arder el Convento de los Dominicos, de la Ciudad Vieja. Por fortuna, no pudieron llevar a cabo los incendiarios su criminal propósito, pues fuerzas de la Guardia civil que allí se presentaron con oportunidad, cargaron enérgicamente contra aquéllos, que los recibieron con denuestos y silbidos. Hubo varios contusos. Una compañía de intendencia rodeó el edificio para evitar que se acercaran a él los incendiarios. También salió del cuartel de Infantería una compañía que fue hasta el edificio incendiado de los Capuchinos, estacionándose en aquel lugar. Fuerzas de Caballería patrullan por la ciudad en previsión de cualquier contingencia.

Saliendo al paso de un infundio: hemos de salir al paso, en honor a la verdad, de una afirmación insidiosa vertida por alguien interesado en excitar a las masas. Cuando el fuego culminaba en imponente haz de llamas, entre el chasquido de los maderos que se derrumbaban, se oyeron una serie de explosiones que no vacilaron en atribuir a la existencia de un depósito de municiones. Un técnico, ingeniero, que allí se encontraba, desmintió dicha especie, pues eran debidas al incendio de las planchas de Uralita que cubrían el templo incendiado"14.

\subsection{Nuevos incendios}

Las manifestaciones del más desenfrenado anticlericalismo con asaltos, saqueos e incendios de iglesias, monasterios y conventos, siguieron teniendo lugar. Llama la atención cómo la fuerza pública no hizo todo lo posible por impedir estos sucesos, y todavía más el que las autoridades respectivas no castigaran tales desmanes.

Los temores de muchos católicos ante la posibilidad de que los incendios funestos de mayo y meses siguientes de 1931 no fueran los últimos y se repitieran en años sucesivos, se hicieron realidad. La impunidad de que gozaron los incendiarios y depredadores de iglesias supuso que continuaran con mayor tenacidad en sus sacrílegas empresas sabiendo que estaban inmunes de cualquier condena. Así lo demos-

${ }^{14}$ El Ideal Gallego XV, 3589, 3 de julio de 1931, p. 1. 
tró el hecho de que las referidas jornadas aciagas de mayo de 1931 se revivieran a lo largo de 1932, en diversos puntos de Galicia... especialmente en octubre ${ }^{15}$.

Resultaba difícil dar cuenta de todos los incendios que tenían lugar en España al ser tantos... Algunos periódicos lo intentaron llegando a contabilizar cerca de un centenar de iglesias, conventos y joyas de arte, atentados, saqueados o incendiados por las turbas impunes. Las autoridades no ponían freno a esta ola de barbarie. Concluía el diario Los Hijos del Pueblo que: "el arte español, de seguir el vandalismo, quedará en pocos años reducido a cenizas". Andalucía aparece como el foco principal del salvajismo de los incendiarios, aunque el triste fenómeno tenía tintes de generalidad.

He aquí el siguiente elenco de templos e imágenes artísticos atentados en Galicia, con pérdidas: iglesia de Carnedo, de Betanzos-Coruña; iglesia parroquial de Cervas-Ferrol; iglesia parroquial de Cabo Cruz, en Vigo, pereciendo el altar mayor ${ }^{16}$. Otro elenco ignominioso es el de conventos e iglesias incendiadas, teniendo noticia en Galicia únicamente de la iglesia parroquial de Ares, Coruña. Y, por último, la lista de conventos e iglesias atentados, sin daños: iglesias de Ayabre y Santa Eulalia de Bairona, Ferrol; iglesia de Santiago de Vigo; iglesia de San Jorge de Mogar, Pontevedra ${ }^{17}$.

Apenas dos meses después, el mismo diario emplea un titular muy similar: "la Semana de la gasolina"18. Su carácter provocativo para nada es gratuito ante los hechos que se reseñan, en esta ocasión centrados en Galicia. Se trata de cinco iglesias quemadas y destruidas, en concreto, la de Bemantes, el templo de Noguerosa, en Puentedeume, y tres en Miño, cerca de El Ferrol. El primer edificio que ardió totalmente fue la iglesia de Becantes, el 21 de marzo. Se cree que el fuego fue intencionado. Aquella misma noche a las doce se incendió el templo de Noguerosa, en Puentedeume. A pesar de que acudió el vecindario rápidamente, no se pudo impedir que la iglesia quedara destruida. Se han practicado seis detenciones, entre ellas la de un hermano del primer teniente alcalde de Puentedeume, quien había incautado hace pocos días los cementerios parroquiales. La opinión pública protesta indignada a la vez que pide que sea retirada la propaganda comunista que se hace en la comarca donde los templos han sido incendiados. El día 25, unos desconocidos incendiaban las tres iglesias ya dichas del pueblo de Miño, las cuales quedaron

15 CÁRCEL ORTÍ, Vicente, La persecución religiosa en España durante la Segunda República (1931-1939), o.c., p. 109.

${ }^{16}$ ABC, 23 de marzo de 1932.

${ }^{17}$ Los Hijos del Pueblo, 5 de enero de 1933, p. 4.

${ }^{18}$ Los Hijos del Pueblo, 30 de marzo de 1933, p. 3. 
totalmente destruidas ${ }^{19}$. Se supone que los autores del hecho son los mismos que hace días derribaron un crucero allí emplazado.

El salvaje atentado produce gran indignación y se pide un castigo ejemplar para que tales hechos no vuelvan a repetirse. La opinión periodística se hace eco de estos actos de salvajismo, y el nuncio Tedeschini informa a la Santa Sede ${ }^{20}$. Pero, lo cierto es que tales atentados vuelven a repetirse en tierra galaica a mediados del mes de mayo del mismo año 1933. En esta ocasión las parroquias que sufren la barbarie son Cigras, Anceis, San Jorge de Iñás, San Pedro de Nós, Oleiros, Pravío... ${ }^{21}$. Por su parte, el nuncio informa de nuevo a la Santa Sede ${ }^{22}$.

En verano, se informa del incendio intencionado que destruye la iglesia de la Magdalena, en Cabañas, Ferrol. Honda consternación produce esta noticia por tratarse de un templo, que era de construcción antiquísima, y "constituía un elemento de gran veneración por parte de los feligreses de toda la comarca"23. Desgraciadamente, los autores del "salvaje atentado no han sido detenidos" 24 .

En septiembre no son muchos menos los vejámenes de carácter antirreligioso. El primero del que se informa es del incendio de la iglesia de Sobrado, el 12 del presente mes. Dice la prensa: "se sospecha quiénes han sido los autores del incendio, y la Guardia Civil los busca. La misma cuadrilla que provocó este incendio asaltó una iglesia días pasados, llevándose algunos objetos de culto. Se han practicado las detenciones de José y Emilio López, que se cree pertenecen a la banda que se busca"25. El diario Ahora también se hace eco de la destrucción de dicha igle$\operatorname{sia}^{26}$, y La Tierra añade que el templo asaltado es de San Cipriano, del que se llevaron varias imágenes ${ }^{27}$. Y, siguiendo en la misma región, se informa de la explosión de una bomba en la puerta posterior de la iglesia de San Andrés de La Coruña, a las nueve de la noche. Apunta: "los daños materiales son escasos" 28.

Llegados al final de un año tan horrible para el patrimonio religioso, es hora de hacer balance. Y, así, lo hace el diario madrileño Los Hijos del Pueblo al contabili-

${ }^{19}$ La Época, 28 de marzo de 1933.

${ }^{20}$ Minuta del nuncio al secretario de Estado. Madrid, 31 de marzo de 1933, en ASV, Arch. Nunz. Madrid, busta 925, tit. VI, rub. 156, sez. 1, n. 15, ff. 244-245.

${ }^{21} A B C, 14$ de mayo de 1933.

${ }^{22}$ Minuta del nuncio al secretario de Estado. Madrid, 16 de mayo de 1933, en ASV, Arch. Nunz. Madrid, busta 925, tit. VI, rub. 156, sez. 1, n. 15, f. 246.

23 El Siglo Futuro, 16 de agosto de 1933.

24 Informaciones, 17 de agosto de 1933.

${ }^{25}$ La Noticia, 12 de septiembre de 1933.

${ }^{26}$ Ahora, 14 de septiembre de 1933.

${ }^{27}$ La Tierra, 14 de septiembre de 1933.

${ }^{28}$ Diario Universal, 28 de septiembre de 1933. 
zar las pérdidas ocasionadas por esta burda manera de actuar en España. El elenco alcanza la cifra de 28 iglesias y conventos, incendiadas y destruidas; 26 templos y casas religiosas que fueron atentadas o sufrieron sacrilegios; numerosas son las cruces derribadas y las imágenes mutiladas y profanadas. Galicia y Asturias aparecen como las regiones más acometidas por los incendiarios. Tal vez, este año haya sido el de una persecución religiosa más intensa, sobre todo por la impunidad de los incendiarios y saqueadores.

Con el fin del primer bienio, y la llegada del nuevo Gobierno de corte conservador, se esperaba una etapa de mayor tranquilidad pública. En este contexto, dicho diario refiere la "luctuosa estadística de atentados sacrílegos, no sólo para confiarla a la Historia, sino para tenerla también presente con la larga lección y por estímulo de actividad para el futuro". Aunque algunos de estos sucesos ya han sido referidos, hay otros de los que no hemos hecho mención, y aparecen en este elenco bien detallado, que reseña lo que sigue - sólo lo que se refiere a Galicia -:

"Iglesias incendiadas en 1933: iglesia de Bemantes (Coruña), tres iglesias de Miño (Ferrol), iglesia de Noguerosa (Puentedeume), iglesia de Cigras (Coruña), iglesia de Anceis (Coruña), iglesia de San Pedro de Nos (Coruña), iglesia de San Jorge de Iñás (Coruña), iglesia de San Cristóbal de Ferrol de Ciervana, iglesia de Nuestra Señora de la Merced de Chanleiro (Ferrol), iglesia de la Magdalena de Cabañas (Ferrol), iglesia parroquial de Sobredo (Ferrol), parroquia de Elviña (Coruña). Éstas figuran como iglesias incendiadas en 1933, y como iglesia gallega atentada la de San Andrés en Coruña. También se registró un atentado contra el palacio episcopal de Tuy al ponerle una bomba" 29 .

Por último, en la primavera de 1935, siguen los atentados antirreligiosos de los que da cuenta el nuncio apostólico a secretaría de Estado. Entre los mismos, se informa de la tentativa de incendio en Vigo, en la parroquia de Mos, de la capilla de Santa Marina, entre otros muchos $\operatorname{casos}^{30}$.

\section{LLEGADA DEL FRENTE POPULAR}

La antigua alianza electoral de socialistas y republicanos reformistas fue reconstituida laboriosamente tras prolongadas negociaciones encabezadas por Manuel

${ }^{29}$ Otro año de vandalismo, saqueos e incendios, en Los Hijos del Pueblo III, 119, 28 de diciembre de 1933, p. 5.

${ }^{30}$ Despacho del nuncio al ministro de Estado. Madrid, 23 de abril de 1935, en ASV, Arch. Nunz. Madrid, busta 925, tit. VI, rub. 156, sez. 1, n. 15, f. 347. 
Azaña e Indalecio Prieto, dirigente socialista y antiguo ministro de la República. Es más, según Federico Suárez, la idea de la constitución del Frente Popular es sobre todo resultado del empeño del señor Azaña ${ }^{31}$.

De sus conversaciones surgirá el Frente Popular, un pacto exclusivamente electoral firmado en enero de 1936 por todas las organizaciones de izquierda, incluyendo en esta alianza al partido comunista. También habría de influir en la determinación de constituir el Frente Popular, la consigna dada por Dimitrof a los comunistas españoles en el VII Congreso Internacional de Moscú de julio-agosto de 1935, que aparece en los siguientes términos:

"Este Gobierno - el del Frente Popular - no será una coalición, pues entonces significaría un Gobierno de lucha contra el sector de izquierda de la clase obrera, mientras que el Gobierno del frente único es de lucha contra el fascismo, que debe despejar el camino para el triunfo de la dictadura del proletariado" 32 .

Se firmó el pacto de unión de los diferentes partidos de izquierda el 15 de enero de 1936, cuya meta común era derrotar a las derechas ${ }^{33}$. Por su parte, Gil Robles abrigaba la esperanza de conseguir la mayoría absoluta, por los escándalos de los radicales durante el último bienio. Pero no fue así, frente a la unión de la izquierda, las derechas no lograron unificarse, ni despertar el entusiasmo de sus partidarios y de la masa nacional española ${ }^{34}$.

"Si en octubre de 1934 la izquierda intentó apoderarse del poder violentamente y fracasó, en las elecciones de 1936 lo consigue por medios democráticos" 35 . El Frente Popular resultó netamente vencedor en las elecciones del 15 de febrero, a pesar de que el número de votos obtenido por él fue sólo un poco mayor que el de la derecha, cuyo apoyo había crecido ${ }^{36}$. De todos modos, hay que decir que los historiadores no se ponen de acuerdo sobre los resultados de dichas elecciones ${ }^{37}$.

${ }^{31}$ SUÁREZ, Federico, Manuel Azaña y la guerra de 1936, Madrid: Rialp, 2000, pp. 106-109.

32 JULIÁ, Santos, Orígenes del Frente Popular en España (1934-1936), Madrid 1979, pp. 84, 94-96.

${ }^{33}$ DE MADARIAGA, Salvador, España. Ensayo de historia contemporánea, Madrid 1978, p. 370.

${ }^{34}$ PLA, José, Historia de la Segunda República, o.c., t. IV, pp. 273-274.

${ }^{35}$ MARTÍ GILABERT, Francisco, Política religiosa de la Segunda República española, Pamplona: EUNSA, 1998, p. 235.

${ }^{36}$ BALFOUR, Sebastian, España desde 1931 hasta hoy, en Historia de España, ed. Raymond CARR, Barcelona: Ediciones Península, 2001, pp. 253-257. Se dan como datos más fiables: Frente Popular, 4.654.000; Centro, 400.901; y Derecha, 4.503.305.

37 SALAS LARRAZÁBAL, Ramón, Los datos exactos de la guerra civil, Madrid: Fundación Vives de Estudios Sociales, 1980, p. 255. 
Aun así, aquella victoria relativa de las izquierdas se transformó en triunfo rotundo gracias a la dejación del Gobierno Portela, que, prematuramente y contra la ley, puso el Estado en sus manos. El 1 de marzo al tener lugar la segunda vuelta electoral, algunos de aquellos resultados fueron alterados a favor de las izquierdas mediante falsificaciones y nulidades de actas, generalizándose el terror y los atropellos para subrayar su triunfo ${ }^{38}$. Claro está, la Santa Sede aparece informada del resultado de las elecciones, del pánico vivido en Madrid en la noche del jueves 21 al viernes 22, del discurso del señor Azaña invitando a la paz y de los primeros desórdenes que se siguen en toda España tras el cambio político ${ }^{39}$. El cardenal Pacelli, siguiendo el informe del nuncio Tedeschini define como "incierta la situación política que derivará en las relaciones con la Iglesia, a pesar de las palabras de paz pronunciadas por el nuevo Presidente del Consejo de Ministros" ${ }^{\prime 4}$.

No era el discurso que esperaban las masas inmersas durante cuarenta días en la oratoria y en la prosa hirviente de la campaña electoral. ¿Qué tenían que ver aquellas apelaciones a la paz, al aquietamiento de las pasiones y al olvido, con la impaciencia acumulada a lo largo de dos años en espera de la hora del desquite? Las masas, en plena embriaguez del triunfo electoral, exigían su revolución. Un ardid oratorio no era bastante para contener y menos para inspirar disciplina y respeto a gentes fogueadas con la demagogia y decididas a cobrarse enseguida cuanto se les había prometido. Dirá, más tarde, Azaña, al referirse a las primeras horas de su Gobierno, en un intento de justificarse que: "nosotros nos hemos encontrado el 19 de febrero del año 36 con un país abandonado por las autoridades" ${ }^{41}$.

Desgraciadamente no faltó el ingrediente de la violencia entre el 17 y el 29 de febrero, e incluso en los días siguientes hasta la fecha del Alzamiento. Pla describe de esta manera aquella delicada situación: "se ha dicho que el 17 de febrero fue un 14 de abril. No es exactamente esto. El 17 de febrero fue un 14 de abril agravado por una repetición del 11 de mayo". El advenimiento de la República había significado una revolución política: el destronamiento. El 17 de febrero era el pórtico de una profunda revolución social que desató mucha violencia contra las "tres fuerzas a las cuales la República declaró la guerra: la Iglesia católica, la propiedad privada y el Ejército"42.

38 CÁRCEL ORTÍ, Vicente, La persecución religiosa en España durante la Segunda República (1931-1939), o.c., p. 184.

${ }^{39}$ Despacho de Tedeschini a Pacelli, n. 7859. Madrid, 22 de febrero de 1936, en ASV, Arch. Nunz. Madrid, busta 912, tit. V, rub. III, n. 77, ff. 519-531.

${ }^{40}$ Despacho de Pacelli a Tedeschini. Ciudad del Vaticano, 2 de marzo de 1936, en ASV, Arch. Nunz. Madrid, busta 912, tit. V, rub. III, n. 77, f. 530.

${ }^{41}$ DS XLIV, 3 de abril de 1936, p. 223.

${ }^{42}$ PLA, José, Historia de la Segunda República, o.c., t. IV, p. 300. 
Los desórdenes comenzaban con el incendio de iglesias y conventos, se prolongaban en actos de terror y terminaban con el asalto a centros políticos y domicilios de los “enemigos del pueblo". La simultaneidad de sucesos de carácter idéntico en diversos sitios, demostraba que no eran espontáneos, sino preconcebidos y dentro de un plan. En muchos sitios las turbas fueron dueñas de las localidades jornadas enteras, sin que nadie les hiciera rostro ni frenara su barbarie. De estos desmanes poco decían los periódicos y las radios, pues la vigilante censura se cuidaba de impedirlo y únicamente transcendían al público algunos de estos sucesos como rumores que al correr de los días ganaron volumen y gravedad ${ }^{43}$.

En la primavera de 1936 se multiplicaron los choques en las calles de las ciudades entre la derecha y la izquierda en medio de una escalada retórica de reproches mutuos. El período de febrero a julio de 1936 fue uno de los más conflictivos de la historia contemporánea. Resultó imposible la colaboración entre la derecha burguesa y la izquierda obrera. Ni las disposiciones legales eran obedecidas, ni respetados los pactos de legalidad.

Se iniciaba un período de cinco meses de anarquía y de falta de autoridad, condicionado el Gobierno por el ímpetu de los revolucionarios, que los exponentes más moderados del ejecutivo no pudieron controlar. El señor Azaña, quien acabaría sustituyendo a Alcalá Zamora en la Presidencia de la República, lo reflejaría de esta manera en una carta:

"Ahora vamos cuesta abajo, por la anarquía persistente de algunas provincias, por la taimada deslealtad de la política socialista en muchas partes, por las brutalidades de unos y otros, por la incapacidad de las autoridades, por los disparates que el Frente Popular está haciendo en casi todos los pueblos, por los despropósitos que empiezan a decir algunos diputados republicanos de la mayoría. No sé, en esta fecha, cómo vamos a dominar esto" 44 .

La extrema izquierda se lanzó de una manera decidida por la senda de la subversión. Los anarquistas, los socialistas más radicales de Largo Caballero, conocido como el "Lenin español", y los comunistas, con ideología y métodos estalinistas, "eliminaban sin contemplaciones incluso a los republicanos más moderados" 45 .

${ }^{43}$ ARRARÁS IRIBARREN, Joaquín, Historia de la Segunda República, o.c., t. IV, pp. 65-75.

${ }^{44}$ DE RIVAS CHERIF, Cipriano, Retrato de un desconocido, vida de Manuel Azaña, seguido por el epistolario de Manuel Azaña con Cipriano de Rivas Cherif de 1921 a 1937, Barcelona: Ediciones Grijalbo, 1981, pp. 665 y 667. Cita tomada de Federico SUÁREZ, Manuel Azaña y la guerra de 1936, o.c., p. 125.

${ }^{45}$ CÁRCEL ORTÍ, Vicente, La persecución religiosa en España durante la Segunda República (1931-1939), o.c., pp. 187-188. 
En algunos lugares hubo manifestaciones con mueras a España y vivas a Rusia. Para nadie era un secreto el proceso de sovietización del país. Hasta tal punto llegaba la descomposición del régimen y de la sociedad que desde el propio Frente Popular se levantaban voces de alerta. Así, Prieto, el 3 de mayo decía en Cuenca:

"La convulsión de una revolución, con un resultado u otro, la puede soportar un país. Lo que no puede soportar un país es la sangría constante del desorden público sin una finalidad revolucionaria inmediata; lo que no soporta una nación es el desgaste de su orden público y de su propia vitalidad económica, manteniendo el desasosiego, la zozobra y la intranquilidad" 46 .

Además, los resultados electorales desacreditaron la estrategia de la CEDA de conseguir una mayoría parlamentaria para derogar las reformas del primer Gobierno de la República. La propia CEDA se vio desbordada por su derecha por dos nuevas formaciones políticas influenciadas por el fascismo europeo. La más importante era el Bloque Nacionalista, dirigido por el monárquico autoritario de derechas José Calvo Sotelo; y una segunda formación más reducida era la fascista Falange, de José Antonio Primo de Rivera, hijo del dictador. Se iba fraguando la demanda de un golpe militar para imponer un Estado autoritario frente a aquel estado permanente de violencia y de deterioro creciente de la democracia.

El Gobierno, consciente de estos planes, trasladó a destinos lejanos a algunos generales sospechosos de conspiración. Franco, que no había decidido si se uniría o no a la conjura, fue desplazado al puesto de mando más remoto: las Canarias. El asesinato de Calvo Sotelo, el 13 de junio, fue un detonante idóneo para el golpe. El 17 de julio, con la convicción equivocada de poder derribar fácilmente la República, el ejército español de África se alzó en Marruecos y fue secundado al día siguiente por guarniciones de toda España. El fracaso del golpe militar desembocó en una guerra civil larga y sangrienta ${ }^{47}$.

\footnotetext{
${ }^{46}$ Cita recogida en SECO SERRANO, Carlos, Historia de España, Barcelona 1967, t. IV, p. 140.

${ }^{47}$ Cfr. SALAS LARRAZÁBAL, Ramón, Situación de la Iglesia en la España Republicana durante la Guerra Civil, en Iglesia, sociedad y politica en la España contemporánea, ed. José Manuel CUENCA TORIBIO, San Lorenzo del Escorial, 1983, pp. 187-231; LABOA GALLEGO, Juan María, Iglesia e intolerancias: la guerra civil, Madrid: Atenas, 1987, pp. 155-159; I cattolici italiani e la guerra di Spagna. Studi e ricerche, ed. Giorgio CAMPANINI, Brescia: Morcelliana, 1987; TUSELL, Javier, El catolicismo mundial y la guerra de España, Madrid: BAC, 1993.
} 


\section{DESMANES ANTIRRELIGIOSOS EN LAS DIÓCESIS GALLEGAS}

La relación de los desmanes antirreligiosos de todo tipo que tuvieron lugar entre febrero y junio de 1936 no puede menos que conmover, y ayudar a sostener la afirmación de que hubo una verdadera persecución religiosa durante el régimen republicano, que se hacía tanto más intensa como extensa tras las elecciones de febrero de 1936. El Frente Popular se veía incapaz de poner orden alguno, si es que su política sectaria no favorecía la configuración de un ambiente tempestivo de terror y barbarie que hacía temer lo peor.

La documentación vaticana complementa esta información, convirtiéndose en un verdadero desfile de incendios de iglesias y conventos, rectorales y centros católicos, profanaciones, robos, incautaciones, sacrilegios, apaleamientos o expulsión de sacerdotes $^{48}$. A continuación, se presentan los datos enviados por las cinco Curias Diocesanas Gallegas a la Nunciatura de Madrid en dos oleadas, del 16 de febrero al 31 de marzo ${ }^{49}$, y del 1 de abril hasta el 20 de junio de $1936^{50}$. Se sigue el orden alfabético teniendo como criterio el nombre de la diócesis, a la vez que el orden cronológico en la exposición de los desmanes antirreligiosos.

\subsection{Lugo}

4.1.1. FEBRERO-MARZO DE 1936

"Eminentísimo Señor: / Los desmanes de carácter antirreligioso, cometidos en esta diócesis, son los siguientes:

$1^{\circ}$. Incendio de la sacristía de la iglesia parroquial de Rivasaltas, a dos kilómetros de Monforte. La iglesia no quisieron quemarla, y no ha padecido nada.

$2^{\circ}$. Expulsión de tres curas, a los que invitaron a ausentarse de sus parroquias.

Todo ello fue ejecutado por pequeños grupos de mozalvetes contra la voluntad de la mayor parte de los feligreses, que no se atrevieron a oponerse por temor a que les quemaran los pajares. Por otras causas (imprudente actuación política, rigor en exigir los derechos parroquiales, etc.) tuvieron que salir de sus parroquias otros seis curas.

48 ARBELOA MURU, Víctor Manuel - BATLLORI MENNE, Miguel, La Iglesia, en Historia General de España y América, t. XVII: la Segunda República y la Guerra, Madrid: Ediciones Rialp, 1990, p. 204, reconocen que "entre los más de 200 muertos de esos meses, no hubo víctimas entre los sacerdotes y religiosos, aunque sí fueron incendiadas numerosas iglesias en casi toda España”.

${ }^{49}$ Desmanes antirreligiosos cometidos en las diócesis españolas, en ASV, Arch. Nunz. Madrid, busta 925, tit. VI, rub. XV, ff. 471-544, que se complementa con lo que hay en la busta 945.

50 Desmanes antirreligiosos cometidos en las diócesis españolas, en ASV, Arch. Nunz. Madrid, busta 967 , fasc. 1 , ff. 11-59. 
De los nueve sacerdotes a que antes me he referido, cuatro han vuelto ya a sus parroquias, y los cinco restantes no es conveniente que vuelvan, porque ya de antiguo los feligreses no les querían.

Con el mayor respeto y profunda veneración besa su Sagrada Púrpura, y se reitera como siempre de Vuestra Eminencia Reverendísima humilde y devoto servidor. I + Rafael, Obispo de Lugo" ${ }^{51}$.

\subsubsection{ABRIL-JUNIO DE 1936}

"Con sentimiento pongo en conocimiento de Vuestra Eminencia que en la última decena del pasado mayo han sido incendiadas en esta Diócesis las iglesias parroquiales de Cruzul, Castro y Vilachá, y en el anejo de Liber. / Las cuatro iglesias estaban solas en el monte, sin casas alrededor, y fueron incendiadas por la noche. Al amanecer, cuando los curas y los fieles se dieron cuenta, estaban las cuatro terminando de arder. Han quedado totalmente destruidas. / También intentaron incendiar la parroquia de Los Nogales, pero en ésta hay casa acerca de la iglesia, y los vecinos impidieron el incendio. / Con profunda veneración besa su Sagrada Púrpura y se reitera, como siempre, de Vuestra Eminencia Reverendísima humilde y devoto servidor. / + Rafael, Obispo de Lugo" 52.

\subsection{Mondoñedo}

\subsubsection{FEBRERO-MARZO DE 1936}

"Cumpliendo el encargo que V. Emcia. Rvdma. se ha servido hacerme en sus respetables letras del 19 del corriente, recibidas anoche, tengo el honor de comunicar a V. E. que los desmanes de carácter antirreligioso ocurridos en esta diócesis después de las elecciones de 16 de febrero último, se han realizado todos en la ciudad de Ferrol y en sus alrededores, y consistieron en los actos siguientes:

Asalto a la residencia de RR. Misioneros del I. Corazón de María, en la calle de las Angusticas de Ferrol, e incendio de todo el mobiliario, previamente arrojado por las turbas a la vía pública. Ocurrió en la tarde del día 20 de febrero.

Asalto a la vivienda del párroco de Serantes, parroquia inmediata a Ferrol, en la misma tarde del día 20. Elementos destacados de la manifestación de Ferrol repitieron en esta casa lo hecho en la Residencia de Misioneros de Ferrol: asaltaron la casa, lanzaron a la calle todo el mobiliario, ropas, libros, archivo parroquial y demás enseres y los quemaron totalmente.

51 Informe del obispo de Lugo a Tedeschini. Lugo, 23 de marzo de 1936, en ASV, Arch. Nunz. Madrid, busta 945, tit. VIII, rub. I, sez. IV, n. 1, f. 408.

52 Informe del obispo de Lugo a Tedeschini. Lugo, 6 de junio de 1936, en ASV, Arch. Nunz. Madrid, busta 967, fasc. 1, f. 183. 
Incendio de la iglesia parroquial de Caranza, parroquia inmediata a Ferrol, la noche del 20 al 21 del mismo mes de febrero. Ardió completamente el templo con su mobiliario; trozos de imágenes fueron arrojados al mar, próximo a la iglesia. Ya fue incendiada esta iglesia otras cinco veces, desde el 12 de agosto de 1932; pero nunca habían sido de gran consideración los efectos del fuego. Ahora quedaron sólo las paredes.

Incendio de la iglesia parroquial de Serantes, en la noche del 26 al 27 de febrero. Las turbas entraron en el templo, apedrearon las imágenes y altares, bailaron dentro de la iglesia, amontonaron el mobiliario y lo quemaron totalmente. Lo que no ardió entonces, volvieron a quemarlo el día 27 por la tarde. Sólo quedaron en pie las paredes del templo y en parte amenazando ruina.

Incendio de la iglesia parroquial, filial, del Villar, el 29 de febrero. Acudieron pronto los vecinos, que apagaron el fuego, y sólo ardió la puerta, algunos muebles y los manteles del altar.

De los tres templos incendiados se había retirado el Santísimo Sacramento. Y en ninguno de los asaltos e incendios hubo agresiones personales: únicamente estuvo en inminente peligro el párroco de Serantes, que, avisado, pudo huir precipitadamente. No se ha detenido a nadie por estos atentados.

Además de los desmanes mencionados, es de notar que a dos párrocos, el de la Graña y el de S. Martín de Cobas, se les amenazó y obligó a marchar de sus parroquias, y fuera de ellas continúan por fundado temor de ser agredidos por elementos revolucionarios de sus feligresías o de Ferrol. Y lo mismo ocurre al de Serantes.

Otros dos, que fueron amenazados, continúan en sus parroquias: el de Doniños y el de Mandiá. Y otro, el de la Barquera, hubo de marcharse también porque le avisaron que le quemarían la casa, si no se marchaba.

También hubo intentos de incendio en la iglesia de Filgueira, de la parroquia de Caranza, y en la de Chamorro, de la de Serantes; pero en ambos casos lo impidió la Guardia Civil, ni eran más de una pareja los incendiarios. Estos fueron detenidos.

Omito la relación de incautación de cementerios, prohibición del toque de campanas en algún lugar a determinadas horas, etc., por no ser directamente objeto de la pregunta que se me hace.

Lamentando profundamente la triste realidad de los hechos sacrílegos relatados, aprovecho esta ocasión para reiterar a V. Emcia. Rvma. los sentimientos de afectuosa veneración, con que reverente beso la sagrada Púrpura de V. Emcia. / + Benjamín, Obispo de Mondoñedo"53.

53 Informe del obispo de Mondoñedo a Tedeschini. Mondoñedo, 25 de marzo de 1936, en ASV, Arch. Nunz. Madrid, busta 945, tit. VIII, rub. I, sez. IV, n. 1, ff. 355-356. 
"Eminentísimo Señor: / Posteriormente a la fecha de 25 de los corrientes, en que tuve el honor de dirigir a V. Emcia. Rvdma. la relación de los desmanes de carácter antirreligioso ocurridos en esta diócesis después de las elecciones del 16 de febrero último, han sucedido, y me comunicaron los párrocos de los lugares respectivos, los dos hechos que a continuación transcribo, con hondo sentimiento, para la completar la relación mencionada:

I. Profanaciones y destrozos en la iglesia de Abad, anejo de Labacengos (provincia de La Coruña y partido de Ferrol). En la noche del 22 al 23 de marzo actual, entraron en dicha iglesia de Santiago Abad, no se sabe quiénes: abrieron el sagrario, rompieron en dos trozos el copón e hicieron desaparecer las sagradas Formas; destrozaron los ornamentos, manteles, candeleros, cruz, incensario y naveta, Misal y Ritual y otros objetos, excepto las imágenes; fracturaron el ara, que dejaron sobre el altar, sin romper el sepulcro; redujeron a pequeños pedazos las velas y derramaron el aceite de la lámpara.

II. Derribo de cruceros en la parroquia de Santa María de Carballido, provincia de Lugo y partido de Villalba. En la misma noche del 22 al 23 del corriente derribaron unos desconocidos, en la expresada parroquia rural, dos cruces grandes de piedra, colocadas fuera del templo y que reciben el nombre de Cruceros. Las dos fueron destrozadas completamente.

Al cumplir el deber de comunicar a V. Emcia. estos tristes sucesos, me complazco en reiterar a V. Emcia. Rvma. los sentimientos de mis afectuosos respetos y profunda veneración, con que me repito de V. Emcia. devotísimo y humilde servidor, que besa reverente su sagrada Púrpura. / + Benjamín, Obispo de Mondoñedo" 54 .

\subsubsection{ABRIL-JUNIO DE 1936}

"En cumplimiento del encargo que V. Emcia. ha tenido a bien hacerme en sus respetables letras de primero del corriente, recibidas anoche, tengo el honor de comunicar a V. Emcia. los desmanes de carácter antirreligioso ocurridos en esta diócesis, desde la fecha de la última relación enviada a esa Nunciatura Apostólica. Fueron los siguientes:

I. Profanaciones y daños en los templos.

1. En Galdo, partido de Vivero y provincia de Lugo, el día 4 de abril y mientas se celebraban cultos vespertinos en la iglesia, explotó en la cañería de

${ }^{668}$ Informe del obispo de Mondoñedo a Tedeschini. Mondoñedo, 30 de marzo de 1936, en ASV, Arch. Nunz. Madrid, busta 945, tit. VIII, rub. I, sez. IV, n. 1, f. 460. 
desagüe de la sacristía un petardo, que produjo desperfectos en la pared y alarma muy grande en los fieles, que hubieron de abandonar precipitadamente el templo.

2. En Vieiro, del mismo partido de Vivero, el 12 del mismo mes fueron colocados cinco petardos, o cartuchos de dinamita, en varios lugares de la iglesia, y al explotar originaron considerables destrozos en el templo, rompieron todos los cristales e hicieron saltar, hecha pedazos, una de las campanas de la torre.

3. En Cazás, partido de Villalba y de la misma provincia de Lugo, fueron robados los badajos de las campanas el día 19 de mayo, sin que hayan aparecido.

4. En Faro, anejo de Cillero, en el partido de Vivero, en la noche del 24 al 25 de mayo, varios individuos penetraron en el templo, por un boquete abierto en la pared, y robaron el copón con las sagradas formas y dos cepillos con algunas limosnas de los fieles para el culto.

\section{NO FUERON DESCUBIERTOS LOS AUTORES DE NINGUNO DE ESTOS DESMANES}

II. Detenciones de sacerdotes.

1. D. Gabriel Bouso Arias, presbítero y abogado con residencia en Ferrol, fue detenido el día 20 de abril en su domicilio juntamente con varios seglares, por habérseles considerado como sospechosos de fascismo; y, a pesar de que no apareció cargo alguno concreto contra él, estuvo preso en la cárcel de aquel partido hasta el 5 del corriente por la noche.

2. D. Eugenio Durán López, presbítero de Vivero, fue detenido en su casa el día 26 de abril, también al mismo tiempo que algunos seglares, por haberse significado como derechistas; pasó algunos días en la cárcel y otros detenido en su propio domicilio.

3. D. Gabriel Pita de Veiga Rodríguez, cura ecónomo de la parroquia de S. Juan de Lagostelle, llamada vulgarmente de Guitiriz, fue detenido el día 18 de mayo por haber distribuido entre sus feligreses (como solía hacerlo todos los domingos) unas hojitas de propaganda catequística y apologética, impresas en Valladolid con el título Verdad y Vida, en algunas de las cuales había unos párrafos sobre la influencia de la Masonería en España y frases que el Alcalde consideró como injuriosas para algunos personajes republicanos de la actual situación. Estuvo un día en la cárcel y varios otros detenido en su propia casa; y, al ser puesto en libertad, quedó multado con doscientas cincuenta pesetas por el motivo enunciado. 
III. Multas a sacerdotes.

1. La expresada en el párrafo anterior, impuesta al cura de Guitiriz por haberse repartido hojas de propaganda impresas en Valladolid y de carácter catequístico y apologético.

2. Otra de veinticinco pesetas al Ecónomo de Valdoviño, porque, al pedir licencia al Ayuntamiento para edificar un local para centro de la Juventud Católica y catequesis, no terminó la instancia con las palabras 'Salud y República', lo cual fue causa de que la instancia fuese tenida por nula y presentada y que, por tanto, fuese considerada como no hecha la petición de la licencia. Impuso la multa el Alcalde de Valdoviño.

IV. Incautaciones de cementerios.

En cierto sentido, pueden considerarse como desmanes los abusos de autoridad que algunos ayuntamientos, como los siguientes: los de Villalba y Trasparga, en la provincia de Lugo, han procedido a la incautación de los cementerios parroquiales sin sujetarse a las prescripciones del Reglamento, como lo habían hecho anteriormente los de Serantes y Ortigueira, en la provincia de La Coruña, pues ninguno de ellos ha querido reconocer el derecho de propiedad de la Iglesia ni, por tanto, pagó indemnización alguna. Y los de Barreiros y Puentes de García Rodríguez, de Lugo el primero y de La Coruña el segundo, exigieron a los Párrocos, antes de incoar el expediente de expropiación, uno de los títulos de propiedad de los cementerios y el último las llaves de los mismos. Esto mismo hizo recientemente el de Cedeira, también en la provincia de La Coruña.

$\mathrm{V}$. Toques de campanas e impuesto a las iglesias.

El ayuntamiento citado de Cedeira prohibió tocar las campanas antes de las 8 de la mañana y después de las 8 de la tarde; y lo mismo había prohibido con anterioridad el de Serantes.

Y el de Trasparga acordó imponer una especie de arbitrio municipal a las iglesias y capillas del concejo, señalando la cantidad de sesenta pesetas anuales para las primeras y la de treinta para las segundas. El acuerdo fue recurrido, pero todavía no resolvieron las autoridades superiores.

Al enviar a V. Emcia. la relación de estos desmanes, cúmpleme reiterarle los sentimientos de filial adhesión a la Santa Sede Apostólica y los de profunda veneración con que me suscribo de V. Emcia. afo. seguro servidor y Capellán, que besa reverente la sagrada Púrpura. / + Benjamín, Obispo de Mondoñedo" 55 .

55 Informe del obispado de Mondoñedo a Tedeschini. Mondoñedo, 7 de junio de 1936, en ASV, Arch. Nunz. Madrid, busta 967, fasc. 1, ff. 144-145. 


\subsection{Ourense}

\subsubsection{FEBRERO-MARZO DE 1936}

"Eminentísimo Señor: / En cumplimiento del honroso encargo que se digna hacerme con fecha 19 del p. p. mes, tengo el honor de significar á V. Eminencia Rvdma. que los desmanes antirreligiosos que aquí hemos sufrido son principal y más dolorosamente las frecuentes profanaciones de las sagradas formas, en templos rurales, que por la incuria de las autoridades civiles y la especial situación topográfica se hallan poco vigilados.

Además de lo dicho, el pasado febrero, los vecinos de Torbeo afiliados al Comunismo se adueñaron de la casa rectoral y fincas de la citada feligresía (enclavada en la provincia de Lugo), expulsando violentamente al que las llevaba en arriendo; ya en octubre de 1934 habían quemado el templo parroquial, por lo que reclamé, aunque inútilmente, en tiempo oportuno, como también lo hice ahora, ante las autoridades civiles, y rogué, por medio de su Apoderado en ésta, al señor Duque de Alba, Patrono de Torbeo, lo hiciese él también por su parte.

Ahora quemaron el templo de Paradellas, anejo de Parada de Sil (ayuntamiento de este último nombre), el de S. Benito de Vilar de Beiro, cerca de Orense, y los objetos todos de culto de Castrelo de Abajo (ayuntamiento de Riós) y de Barbadanes (ayuntamiento de este último nombre); se adueñaron de la casa y fincas de la parroquia de Cudeiro, inmediata á la Capital, pero de éstas han sido desalojados por orden del Sr. Gobernador Civil, quien, al parecer, ya comienza a atender mis ruegos y ampara al clero a quienes venían caminando para que en determinados plazos abandonasen sus respectivas feligresías, cosa que, excepto en Cudeiro, no lo han logrado, porque han sabido sostenerse en sus puestos dignamente. Al párroco de Palmés le pusieron una bomba en su casa rectoral, causándole desperfectos de alguna consideración.

Ya tendré á V. Emcia. Rvdma. al tanto de lo que pueda ocurrir en lo sucesivo. Dios guarde á V. Emcia. Rvdma. ms. as. / + Florencio, Ob. de Orense" ${ }^{56}$.

"Eminentísimo Señor: / Tengo el sentimiento de comunicar a V. Eminencia Rvdma. que, con posterioridad a mi oficio de 6 del actual, ha sido quemado el templo parroquial de Barbadanes, del que solamente han quedado la fachada y muros, éstos ruinosos. Aunque el pueblo, que vino en manifestación al Gobierno Civil, para protestar de tal desmán, señala a los probables, sino directos autores, por lo menos cooperadores e inspiradores, ninguna medida se ha tomado con ellos, teniéndose la impresión de estar huérfanos de autoridad, por lo que afecta a la Civil, en esta Provincia.

56 Informe del obispo de Orense a Tedeschini. Orense, 6 de abril de 1936, en ASV, Arch. Nunz. Madrid, busta 945, tit. VIII, rub. I, sez. IV, n. 1, f. 478. 
Además, ha sido detenido por orden gubernativa, sin motivo alguno que lo justifique, ni aún como pretexto, el dignísimo párroco de Ourantes. Para lograr su libertad, a petición mía, hizo gestiones ante el Sr. Gobernador Civil el digno Diputado a Cortes don Ramón Villarino de Saá, a quien prometió el señor Gobernador que sería inmediatamente puesto en libertad, cosa que no ha cumplido aún, llevando ya dos días en la cárcel de Orense el referido sacerdote. Se dice que piensan detener aún más párrocos, sin que se vea motivo alguno para ello, sin duda para llevar el terror al ánimo de los vecinos en estos días precursores de las elecciones a compromisarios, no obstante ser del dominio público que los elementos de derecha se abstienen de intervenir en tal contienda. / Dios guarde a V. Emcia. Rvdma. ms. as. / + Florencio, Ob. de Orense ${ }^{57}$.

\subsubsection{ABRIL-JUNIO DE 1936}

"A su amable 'saluda' de $1^{\circ}$ del actual, tengo el honor de corresponder, significándole que, desde mi última comunicación sobre desmanes cometidos contra bienes eclesiásticos, sacerdotes y culto, hemos tenido que lamentar la incautación de la Casa Rectoral de Medos, anejo de San Clodio, en la provincia de Lugo, llevada á efecto por las turbas á las órdenes del Alcalde quien se niega á reintegrarla.

Igualmente, hemos tenido que sufrir el incendio del templo parroquial de Belle, en las inmediaciones de esta Capital, perpetrado a las tres de la madrugada de ayer, domingo; bien que el auxilio de los fieles impidió fuese total, reduciéndose, según las últimas noticias recibidas a parte de la techumbre y algún altar.

En el ayuntamiento de Boborás, se incautó el ayuntamiento, sin trámites legales, del cementerio de Regueiro; lo mismo hizo el Alcalde de Porquera con el cementerio-atrio de San Juan de Paradela, de cuyas incautaciones se hicieron las debidas reclamaciones.

Son numerosas las amenazas á los párrocos, para amedrentarlos, para que abandonen las parroquias y hasta al ecónomo de Corbelle, en el ayuntamiento de Bande, pretenden obligarle a que ajuste el ceremonial de entierros al arbitrio del Alcalde, según éste dice que hacen en América.

El Alcalde de Celanova ofició al párroco de Freijo, obligándole a tener abiertas de par en par las puertas del templo, durante las horas en que se celebran actos de culto, á pretexto de exigirlo la Higiene; pero se adivina la intención de que así estorben los cultos los grupos que quieren ir a cantar la Internacional y otros cantos similares.

${ }^{57}$ Informe del obispo de Orense a Tedeschini. Orense, 21 de abril de 1936, en ASV, Arch. Nunz. Madrid, busta 945, tit. VIII, rub. I, sez. IV, n. 1, ff. 477-478. 
Estos días están los ánimos de los izquierdistas muy exaltados, por la muerte de unos comunistas ocurridas ayer y se teme que haya nuevas violencias. Si algo ocurriere, lo que Dios no permita, me apresuraré a participarlo a V. Emcia. Reverendísima.

Disponga siempre a su completa voluntad de su afmo. servidor y capellán, q. 1 . b. 1. S. P. / + Florencio, Obispo de Orense" 58 .

"Cumpliendo las órdenes de V. Emcia. Rvdma., tengo el sentimiento de participarle que continúan, cada vez con más intensidad, los atropellos contra la Iglesia y sus ministros por parte de las gentes maleantes, dirigidas, según fácilmente se comprende, por órdenes de alguna organización atea y amparadas por la falta de autoridad, cuando no directamente capitaneadas por alcaldes que no son de elección popular.

El día de ayer han sido incendiados los templos de San Miguel de Melias y Santa Cruz de Rabeda, ambos próximos a esta Capital, habiéndose podido localizar el fuego en el primero de los citados, del que ardió la Sacristía con todos los ornamentos en ella custodiados, muchos y de buena calidad; y quedando destruido por completo el segundo, del que solamente quedaron las paredes.

En ese mismo día han sido encarcelados tres sacerdotes, sin que se haya concretado contra los mismos acusación alguna. Han sido llevados primeramente dos de ellos, de los mejores de la diócesis ciertamente, a la casa consistorial de Amoeiro, a cuyo ayuntamiento pertenecen, donde estuvieron custodiados por "guardias rojos", armados de palos, maltratados de palabra y hasta robados, y ahora conducidos á la Cárcel de esta Capital. Entretanto, se permite que la chusma ponga en libertad a procesados por diversos delitos.

No censa las amenazas a los curas, para que abandonen las parroquias, ni se toma por la competente autoridad medida alguna con los que tales coacciones cometen. Parece adivinarse que, si no los ordenan, por lo menos los ven con agrado.

Bien quisiera, Eminentísimo Señor, poder comunicarle noticias más gratas y quiera el señor que estas penalidades que la Iglesia viene sufriendo produzcan abundantes frutos de santificación.

Con los más vivos sentimientos de afecto y veneración, saluda a V. Emcia. Rvdma. su humilde servidor y capellán, que besa S. P. / + Florencio, Obispo de Orense" 59 .

58 Informe del obispo de Orense a Tedeschini. Orense, 8 y 11 de junio de 1936, en ASV, Arch. Nunz. Madrid, busta 967, fasc. 1, f. 171r-v.

${ }^{59}$ Informe del obispo de Orense a Tedeschini. Orense, 8 y 11 de junio de 1936, en ASV, Arch. Nunz. Madrid, busta 967, fasc. 1, f. 172r-v. 


\subsection{Santiago de Compostela}

\subsubsection{FEBRERO-MARZO DE 1936}

"Relación de los desmanes de carácter antirreligioso cometidos en esta archidiócesis a partir del 19 de febrero pasado.

Provincia de Pontevedra: en esta provincia (por lo que se refiere a esta archidiócesis) no se sabe que se haya cometido ningún desmán de este carácter. Lo que sí se sabe es que los obreros de Pontevedra en una de sus reuniones cambiaron impresiones entre ellos sobre si sería prudente o no expulsar a las monjas de Santa Clara de aquella ciudad, y resolvieron que no procedía porque éstas no hacían daño alguno.

Provincia de la Coruña:

Santiago: en la noche del 19 del pasado mes las turbas asaltaron el Centro de Acción Católica, y aparte de otros desmanes, lo más lamentable fue la profanación de una imagen de la Inmaculada, arrojándola a una fuente pública y cometiendo con ella y otras imágenes algunas irreverencias. En la misma noche asaltaron también estar turbas el Centro Tradicionalista y arrojaron a la calle una imagen del Sagrado Corazón de Jesús, arrastrándola después.

En la madrugada del día primero de marzo los obreros afiliados a la U. G. T. y C. N. T. se apoderaron por sí y ante sí del edificio anexo a la iglesia de San Agustín (antigua residencia de los PP. Jesuitas) violentando para ello las puertas y derribando muros y paredes, y ocupando no sólo la parte que quedó reservada para el ayuntamiento, sino también la que se reservó para la mitra. Se levantó inmediatamente acta notarial y se dio cuenta del caso al Sr. Delegado de Hacienda y al Sr. Gobernador de la Coruña.

El día 21 de los corrientes, se presentaron en esta Iglesia de San Agustín varios guardias de Asalto y Policías, quienes procedieron a cachear a los jóvenes Luises, no sólo a las puertas del templo sino también dentro del mismo y sus dependencias, incluso a los sacerdotes, registrando la sacristía, confesonarios, etc.

La Coruña: también en esta ciudad se apoderaron las turbas del edificio anexo a la iglesia de los PP. Jesuitas y desde allí penetraron en la misma prendiendo fuego a los altares y algunos objetos de culto que se guardaban en la sacristía. Gracias a la rápida intervención de los bomberos fue sofocado el incendio sin más consecuencias que algunos desperfectos en los altares y la pérdida de varios objetos de culto, algunos de gran valor. Lo más lamentable fue la profanación de un crucifijo, la desaparición del copón con las SS. Formas, un cáliz y una custodia.

Asimismo prendieron fuego a la iglesia de la Colegiata, a la capilla y residencia de los PP. Redentoristas y a la iglesia de los Terciarios; pero al punto fue sofocado y no sufrieron éstas más que algunos desperfectos. 
Se intentó incendiar la iglesia de San Roque y el Colegio de las Religiosas Josefinas.

Pueblos de la provincia de La Coruña:

Requián: el cura ecónomo se vio obligado a salir de su parroquia ante la actitud hostil de varios feligreses suyos, quienes se apoderaron de las llaves de la iglesia, de la casa rectoral y de cuatro cálices.

Mondoy y Porzomillos: una comisión de socialistas y comunistas se apoderó de las dos iglesias para convertirlas en escuelas, de la cruz parroquial, de varios ornamentos sagrados y cuatro imágenes, prohibiendo además al párroco tocar las campanas y celebrar en estas iglesias ningún acto religioso.

Vijoy y Cortiñán: el párroco tuvo que abandonar la parroquia ante la presión de un núcleo de sus feligreses, quienes intentaron apoderarse de la iglesia y casa rectoral.

Betanzos: las religiosas agustinas fueron expulsadas de su convento por el Alcalde, obligándolas a salir de la ciudad. Asimismo los PP. Franciscanos que fueron traídos a esta ciudad de Santiago al convento de la misma orden.

Vimianzo: este ayuntamiento tomó el acuerdo de incautarse de todos los cementerios parroquiales de aquel distrito municipal, sin tener en cuenta para nada la circunstancia especial de estar éstos enclavados en los atrios de las iglesias.

Maniños: las turbas prendieron fuego a varias imágenes, pero por fortuna no sufrieron éstas más que algunos desperfectos.

Limodre: ardió la sacristía de esta parroquia, se quemaron todos los ornamentos y varios objetos de culto, valorándose las pérdidas en seis mil pesetas.

Verdes: fue asaltada la iglesia y descerrajados varios cepillos destinados a recoger limosnas.

Malpica: al llegar a esta parroquia el día 18 de este mes dos PP. Redentoristas, encargados de dar una Misión al pueblo, se vieron obligados a retirarse inmediatamente ante la actitud hostil de un grupo de mozalbetes.

Arteijo: este ayuntamiento ofició a todos los curas del distrito municipal diciéndoles que en el plazo de 15 días se presentaran en aquella Alcaldía para acreditar en forma los derechos que tuviesen sobre los bienes inmuebles que poseen o administran, ya que éstos pudieran ser muy bien bienes comunales. El delegado de Hacienda ha intervenido en este punto, invocando el art. 12 de la Ley de Confesiones y Congregaciones religiosas. / + Tomás, Arzobispo de Santiago"60.

${ }^{60}$ Informe del arzobispo de Santiago de Compostela a Tedeschini. Santiago, 25 de marzo de 1936, en ASV, Arch. Nunz. Madrid, busta 945, tit. VIII, rub. I, sez. IV, n. 1, ff. 430-431. 


\subsubsection{ABRIL-JUNIO DE 1936}

"En ausencia del Rvdmo. Sr. Arzobispo, que se halla practicando la Santa Visita Pastoral, remito a V. Emcia. la Relación adjunta, con la sucinta exposición de los desmanes de carácter antirreligioso que se han cometido en esta archidiócesis, desde la última relación enviada a esa Nunciatura, a fines de Marzo pasado. Dios guarde a V. Emcia. muchos años. / Santiago, 8 de Junio de 1936. / Dr. Fernando Peña.

Relación de los desmanes de carácter religioso cometidos en esta Archidiócesis.

A la relación enviada a esa Nunciatura a fines de marzo próximo pasado, hay que añadir lo siguiente:

29 de febrero - Andabao: un grupo de campesinos, armados varios de ellos de escopetas, y capitaneados por el alcalde, Pedro López, sacó violentamente de la rectoral al Párroco, maltratándole y amenazándole de muerte, por lo que tuvo que salir de la parroquia, y actualmente continúa fuera de ella.

9 de abril - Mántaras: en la noche de este día fueron rotos todos los cristales de la casa rectoral, en la filial de Corujou.

9 de abril - Dordaño: en la noche de este día fue robada la campana de la capilla del Rosario.

19 de abril - Villamayor (Santiago de): un grupo de personas, se apoderaron del párroco, y lo llevaron a Órdenes para que fuera encarcelado como fascista, cosa que evitó el Sr. Gobernador Civil de la provincia.

22 de abril: fueron detenidos y conducidos a la Casa Consistorial de Vimianzo, por orden del alcalde, los párrocos de Salto, Castrelo y Baiñas, a los que se libertó poco después.

25 de abril - Almeiras: en la noche de este día fue quemada totalmente la iglesia parroquial, de la que sólo quedaron las paredes.

30 de abril - Nós e Iñás: en la noche de este día fue incendiada la iglesia de la filial, Iñás, quedando completamente destruida la sacristía, ornamentos, varios bancos e imágenes (f. 128), y con desperfectos en toda la iglesia.

5 de mayo - Bamio: en este día fue incendiada la capilla de San Juan, que sufrió grandes desperfectos, y robados varios objetos de culto, que aparecieron luego destrozados.

5 de mayo - Noya: fue asaltado el local de la Juventud Católica, se dio orden de detención contra el presbítero, consiliario, D. Serafín Rivera Verdes, que no fue habido; posteriormente el Sr. Gobernador Civil, ha rogado que ese consiliario sea trasladado.

2 de mayo - Leira, Santa María: se intentó quemar la iglesia parroquial, aunque sólo ardió totalmente la puerta principal.

6 de mayo - Vilaboa - Rutis: un grupo de unos trescientos obreros asaltó la casa rectoral, que ha sido convertida en Casa del Pueblo, y así continúa en la actualidad. 
4 de mayo - Bértola: fue asaltada la capilla de Santa Marta, destrozado el altar y arrojado fuera, con propósito de convertirla en casa del pueblo, lo que evitó la Guardia Civil.

17 de mayo - Meirás: varios grupos, llegados en camiones, de Coruña y Betanzos, asaltaron la casa rectoral, desalojando, destrozando o robando la mayor parte de los muebles y enseres.

17 de mayo - Montaos: intimación al cura, por un grupo de comunistas, para que en el término de ocho días, abandonara la parroquia; el cura, no obedeció, y días después arrojaron en su casa una bomba que no estalló.

17 de mayo - Brives: varios individuos conminaron al cura para que antes de 24 horas abandonara la parroquia, con amenazas, de no hacerlo; por lo que el Sr. Cura tuvo que salir de ella.

17 de mayo - Calvos de Sobrecamino: varios revoltosos arrebataron al Sr. Cura las llaves de la iglesia, pretendieron asaltar la rectoral, y destrozar los muebles, dando finalmente un plazo de ocho horas para que el Sr. Cura la desalojara.

23 de mayo - Viceso y Ons: fueron robados los badajos de las campanas de la iglesia de Ons.

25 de mayo - El Eijo: fue robada la capilla de Santa Lucía; desapareció la imagen de la Cruz del altar mayor y varios ornamentos.

Vijoy: en esta parroquia no han consentido la entrada del ecónomo; se han incautado de la rectoral, incluso el archivo y han asaltado la iglesia; el ecónomo no halla una casa en donde poder hospedarse.

6 de junio - Visantoña: a título de fascista, aunque con la protesta de los feligreses, es encarcelado en Órdenes, el Sr. Párroco, D. Manuel Romero, sin que haya recobrado la libertad, hasta esta fecha.

Mugardos: la corporación municipal, se ha incautado del cementerio parroquial, sin indemnización.

31 de mayo - Presedo: elementos comunistas asaltaron la iglesia parroquial, destrozando todo lo que encontraron al paso, sin que apenas quedara ningún objeto servible.

1 de junio - Callobre: fueron incendiadas varias imágenes de la capilla de Guadalupe.

Además, hay varios párrocos, como los de Cambre, Meirás, Sigrás, Prendes, Vijoy, Andabao y Rodeiro, que han tenido que abandonar sus feligresías bajo la coacción de elementos extremistas"61.

${ }^{61}$ Informe del arzobispado de Santiago a Tedeschini. Santiago, 8 de junio de 1936, en ASV, Arch. Nunz. Madrid, busta 967, fasc. 1, ff. 126-129. 


\subsection{Tuy}

4.5.1. FEBRERO-MARZO DE 1936

"Eminencia Reverendísima: en contestación a su respetable comunicación del día 19 de los corrientes, me complazco en participar a V. Em. que en los pasados días no se ha verificado en esta diócesis, gracias a Dios, ningún desmán con carácter antirreligioso.

$\mathrm{Al}$ tener el honor de poner esto en conocimiento de V. Em. Rvdma. le reitero mis sentimientos de veneración y afecto con que me suscribo afmo. $\mathrm{H}^{\circ}$. y s. s. que besa la S. Púrpura de Vuestra Eminencia. / + Antonio, Obispo de Tuy"62.

\subsubsection{ABRIL-JUNIO DE 1936}

"Tengo el honor de contestar a su respetable Circular del 1 del corriente y a la vez el sentimiento de comunicarle los desmanes antirreligiosos cometidos en esta Diócesis, han sido los siguientes:

1. En la parroquia de Santa María de Areas fue saqueada e incendiada una ermita y quemados algunos enseres e imágenes en el camino, eran cosas de poco valor.

2. En la de Comesaña fue saqueado e incendiado el local de la Juventud Masculina de Acción Católica, con todos los muebles y libros.

3. En la de Arbo fue robada en la iglesia parroquial una pequeña cantidad de los cepos de limosnas.

4. Desmán semejante se cometió en la parroquia de Beade, el Arciprestazgo de Ribadavia.

5. En la de Porriño fue incendiada la capilla del Santo Cristo y ardió parte del altar.

6. En la ciudad de Tuy fueron detenidos y encarcelados varios días tres sacerdotes: D. Casiano Quiroga, párroco de Malvas, D. Servando Bugarín, ecónomo de Rebordanes, y D. Francisco Saa Aldir, coadjutor de la de Tuy. De nada se les inculpó.

7. En Salceda fueron detenidos, de orden del alcalde, trece sacerdotes, que estaban reunidos con el Arcipreste para acordar el itinerario de la Visita Pastoral; el prelado recurrió al Sr. Gobernador Civil y enseguida fueron puestos en libertad.

8. El ecónomo de Oroso fue encarcelado y permaneció así dos meses; y el párroco de Villasobroso unos 15 días; ya están en libertad. Tampoco hasta ahora han sido inculpados de nada ante la Autoridad Diocesana.

9. Al párroco de Salcidos se le multó con 250 pesetas por sacar una procesión, para la cual tenía licencia verbal del alcalde. Al de Tomiño, con 25 pesetas, por salir con la Santa Cruz a bendecir las casas el día de Sábado Santo.

${ }^{62}$ Informe del obispo de Tuy a Tedeschini. Tuy, 24 de marzo de 1936, en ASV, Arch. Nunz. Madrid, busta 945, tit. VIII, rub. I, sez. IV, n. 1, f. 367. 
10. Se han cometido algunos otros desmanes, pero de muy poca monta, como denuncias contra sacerdotes, sin efecto alguno, etc.

Como puede apreciar, Emmo. Señor, esta diócesis no ha sido de las más atribuladas. El ataque más fuerte de irregularidad fue el intento, por parte del ayuntamiento de Tuy, de apoderarse del Seminario, de que ya di cuenta a V. Emcia., y hoy me complazco en añadir que el acuerdo, suspendido por el Excmo. Gobernador Civil, ha sido anulado por el Tribunal de lo Contencioso Administrativo de esta Provincia. Con esta ocasión me honro de nuevo en ofrecerme a V. E. R. como afmo. s. s. y a. y H. I + Antonio, Obispo de Tuy" ${ }^{2}$.

\section{LA DESATENCIÓN PASTORAL}

Una de las consecuencias que se siguen de las prácticas anticlericales descritas y llevadas a término con acritud en tierras galaicas fue la desatención pastoral de varias aldeas y poblaciones. A excepción de la diócesis lucense, de la que no consta informe alguno, presentamos a continuación los estudios que refieren el estado de las demás diócesis gallegas donde sí hay algunas feligresías que no pudieron contar con su respectivo pastor por falta del necesario respeto y la debida libertad religiosa que requería el ejercicio pastoral.

Además, las dolorosas circunstancias porque atravesaba la Iglesia en España y la angustiosa situación creada al Culto y Clero de la misma con la supresión del presupuesto destinado concordatariamente a su sostenimiento en los del Estado, impusieron a la Santa Sede la necesidad de conocer del modo más exacto posible cuál era la verdadera situación económica de las distintas diócesis. Por eso, en los informes referidos también consta el precario estado económico de tantas parroquias, que, aunque no se nombran, en el caso de Galicia, fueron muchas, debido al carácter eminentemente rural de nuestro territorio.

Era un hecho contrastado que dentro de cada diócesis había un número de parroquias que por sí solas no podían subvenir a sus propias necesidades, existiendo también otras instituciones de carácter diocesano que no tenían dotación propia: Obispo, Catedral, Seminario, párrocos jubilados, sacerdotes sin congrua, construcción de templos, reparaciones extraordinarias de edificios eclesiásticos... Asimismo, algunas diócesis por sí solas no tenían potencia económica suficiente para cubrir todas las atenciones del culto y clero, además de haber sido despojadas de sus anti-

${ }^{63}$ Informe del obispado de Tuy a Tedeschini. Tuy, 8 de junio de 1936, en ASV, Arch. Nunz. Madrid, busta 967 , fasc. 1 , f. 146. 
guos bienes, con lo que no percibían rentas que de alguna manera compensaran el despojo padecido y que en el porvenir se habría de agravar. Por otra parte, hay que observar el hecho de que los fieles rehusaban dar para necesidades que no fueran las de su parroquia, y aún así resultaba harto complicado porque los fieles no tenían todavía la necesaria instrucción acerca de sus deberes para con la Santa Iglesia en este punto ${ }^{64}$.

\subsection{Mondoñedo}

"Al regresar de la Santa Pastoral Visita, tengo el honor de contestar a la muy atenta carta circular de V. I., fecha 29 de junio último, para manifestarle que en esta Diócesis, gracias a Dios, todas las parroquias están atendidas en el servicio religioso. Sólo diez carecen actualmente de Cura Párroco o Ecónomo; de las cuales siete están unidas provisionalmente a otras inmediatas, prestando en ellas los servicios religiosos los Párrocos de estas últimas, por ser curatos pequeños y que no pueden sostener Ecónomo propio, y de otras tres tuvieron que marchar los Párrocos, a consecuencia de los desmanes ocurridos o temidos en las mismas, estando encargados de atenderlas sacerdotes cercanos, mientras no pueden volver los Curas propios o se provee de un modo estable, por otra vía, al régimen de las parroquias. / Al comunicarlo así a V. I., me complazco en expresarle los sentimientos de más alta estima, con que me suscribo de V. I. affmo. s. s. / + Benjamín, Obispo" ${ }^{65}$.

\subsection{Ourense}

"Cumpliendo gustoso el encargo que V. S. I. me hace en su atenta comunicación, $\mathrm{n}^{\mathrm{o}} .67$, de 29 de junio próximo pasado, tengo el honor de participarle que en esta Diócesis hay no pocas parroquias que, por su escaso vecindario, pobreza del mismo e insuficiencia de medios económicos para sostener sacerdote propio que en las mismas residen, están regidas por párrocos inmediatos á ella; quienes binan la Santa Misa, ponen catequesis y hacen todos los servicios como en la propia parroquia, salvo la residencia, por lo cual interpreto que la pregunta de V. Señoría Ilma. no se extiende á esta clase de feligresías; si así fuere, le agradeceré se digne significármelo, para remitirle nota detallada de las mismas. / Propiamente desprovistas de asistencia religiosa se hallan las siguientes: Torbeo, de unas 1045 almas; Ribe-

${ }^{64}$ Observaciones e indicaciones acerca de la creación de cajas diocesanas, provinciales y nacional para las necesidades del Culto y Clero en España. Tuy, mayo 1932, en ASV, Arch. Nunz. Madrid, busta 947 , tit. VIII, rub. I, sez. VI, fasc. 1, ff. 9-10.

${ }^{65}$ Informe del obispo de Mondoñedo a Tedeschini. Mondoñedo, 12 de julio de 1936, en ASV, Arch. Nunz. Madrid, busta 967, fasc. 1, f. 304. 
la, de 623; Mazaira, de 393; Medos, de 176; Noalla, de 544; Pazos, de 366; Cudeiro, de 1295; Bóveda de Amoeiro, de 650; Canedo, de 915; y Toubes, de 585 almas.

De todas estas antedichas parroquias han sido violentamente expulsados los respectivos sacerdotes por grupos de comunistas, sin que la autoridad civil, a la que en cada caso hemos acudido, hubiese impuesto el orden y reparado la injusticia y atropello, no obstante haberlo prometido. Continúan coaccionando en otras feligresías y atemorizando a los párrocos con amenazas de muerte, por lo que de temer es que el número de parroquias abandonadas aumente. / Dios guarde á V. S. I. muchos años. I + Florencio, Obispo de Orense" ${ }^{\text {"66. }}$.

\subsection{Santiago de Compostela}

"En contestación a su atento oficio, n' .67 , de 29 de junio pasado, tengo el honor de manifestarle que las parroquias que se hallan actualmente desprovistas de asistencia religiosa en esta diócesis son las que se mencionan en la siguiente relación, aunque es de advertir que todas ellas, excepto la de Vilaboa, tienen asistencia por lo que se refiere a sacramentos, prestada por algún sacerdote limítrofe. Dios guarde a V. E. muchos años. I + Tomás, Arzobispo de Santiago.

Se hallan actualmente desprovistas de asistencia religiosa las siguientes parroquias:

Andabao: 660 feligreses. Fue expulsado el cura violentamente, se le permite servir el anejo.

Arteijo: 1650 feligreses. El alcalde no consiente que vuelva el cura a la parroquia.

Brives: 600 feligreses. Tuvo que marcharse el cura por amenazas.

Brejo: 600 feligreses. Fue expulsado violentamente el cura.

Cambre: 1875 feligreses. Fue expulsado el Sr. Cura.

Calvos de Sobrecamino: 700 feligreses. Fue expulsado el cura.

Crendes: 700 feligreses. Fue expulsado el Sr. Cura.

Meirás: 1500 feligreses. Fue expulsado el Sr. Cura, se consiente al coadjutor que preste servicios religiosos.

Montaos: 1000 feligreses. Expulsaron y apalearon al Sr. Cura.

Orro: 350 feligreses. No admiten al cura.

Orto: 400 feligreses. Estaba encargado de esta parroquia el cura de Brejo, que fue expulsado.

Rodeiro: 700 feligreses. Arrastraron y expulsaron al cura.

${ }^{66}$ Informe del obispo de Orense a Tedeschini. Tuy, 11 de julio de 1936, en ASV, Arch. Nunz. Madrid, busta 967, fasc. 1, f. 319r-v. 
Vijoy: 1500 feligreses. Expulsaron al cura y han querido admitir al sustituto que se les nombró.

Vilaboa (Rutis): 3000 feligreses. No quieren admitir ningún sacerdote, ni para sacramentos.

Villamayor (Santiago): 1000 feligreses. Fue expulsado el cura.

Las dificultades principales para restaurar la asistencia religiosa, radica principalmente en la oposición de las autoridades locales y en la falta de apoyo en las autoridades superiores" $" 67$.

\subsection{Tuy}

"En contestación a la respetable comunicación de V. S. Ilma., nº. 67, recibida ayer, me complazco en manifestarle que en esta diócesis no hay parroquia alguna desprovista de asistencia religiosa. Hay no pocas encomendadas a un párroco vecino; pero éste atiende a las dos binando la Santa Misa y cumpliendo los demás deberes parroquiales en las dos en cuanto es posible. La razón por que un solo sacerdote está encargado de dos parroquias es la escasez de sacerdotes. Sólo hay algunas parroquias, muy pocas, que durante algún tiempo no han podido tener ni siquiera esta asistencia espiritual, aunque sin quedar totalmente desprovistas; pero actualmente preparo una combinación de personal, utilizando los presbíteros recientemente ordenados, y con ella mejorará notablemente, así lo espero, el servicio espiritual de muchas parroquias.

Agradezco profundamente los ofrecimientos de V. S. Ilma. y aprovecho esta ocasión para darle la bienvenida a la Nunciatura de Madrid. Que el Señor bendiga copiosamente los trabajos de V. S. Ilma., y téngame por su afmo. s. y a. q. e. s. m. I + Antonio, Obispo de Tuy" 68 .

Las cosas fueron como fueron y no como otros nos las contaron o nos las quieren ahora contar. Tampoco fueron como a nosotros nos hubiera gustado que fueran. Por ello, hemos dejado hablar a los documentos y a quienes los han redactado. De los archivos vaticanos salen estos informes inéditos que hacen resplandecer la verdad, esa verdad que ninguna ideología puede manipular para intereses partidistas. Solamente después de conocer esta relevante documentación y con ello, los hechos que constituyen la memoria histórica verídica, el lector podrá sacar sus propias conclusiones.

${ }^{67}$ Informe del arzobispo de Santiago de Compostela a Tedeschini. Santiago, 4 de julio de 1936, en ASV, Arch. Nunz. Madrid, busta 967, fasc. 1, ff. 269, 323.

${ }^{68}$ Informe del obispo de Tuy a Tedeschini. Tuy, 4 de julio de 1936, en ASV, Arch. Nunz. Madrid, busta 967, fasc. 1, f. 346. 